\title{
Land Economics vs Land Use Planning
}

\author{
Mishra BB* \\ School of Natural Resource Management \& Environmental Sciences, Haramaya University, Ethiopia
}

Submission: February 02, 2016; Published: August 25, 2017

*Corresponding author: BB Mishra, School of Natural Resource Management \& Environmental Sciences, Haramaya University, Ethiopia, Email: bbmsoil@rediffmail.com

\begin{abstract}
Today's lifestyle and high-tech economic race above the ground is challenging to the global sustainability. We need air, water, food and ecosystem for our existence and survival and so we need technologically sound land use planning (LUP) in its broad spectrum in order to insure overall sustainability of the land units as well as environment and assure profitability of the land uses that we identify at planning stage in a given land unit, but on the background of economics. The land use or land produce is a subject to insure profitability. Thus, the concept of land economics is very relevant to make our land use profitable by applying economic principles within the control of farmers. Importantly, adoption of conservation agriculture based on land evaluation will significantly help in building up not only a healthy soil and producing quality food, but also for sequestering carbon in soil significantly preferably on continued basis.

The agri-business techniques including the supply chain process will simultaneously help to alleviate the poverty in a big way. Thus, land economics must be included in course curriculum in Universities across the globe to insure overall sustainability of our land/soil. The Food and Agriculture Organization of UNO may preferably work on this line to approve the criteria of how best land economics would be the driving force to streamline the approaches under LUP leading to poverty alleviation, continued carbon sequestration, organic farming and quality food production by restoring the overall soil health. Land economics may be a powerful tool for climate change adaptation-mitigation including poverty alleviation.
\end{abstract}

Keywords: Land economics; Land use planning; conservation agriculture; Food safety; Climate change mitigation; Poverty alleviation

\section{Introduction}

Land is merely an area of the earth's surface comprising of all physical, chemical and biological environment that influence the land use as outlined by FAO. Obviously, land refers not only to soil but also climate, landforms, hydrology, geology, natural vegetation including fauna and flora. The land use simply means for management of a land to meet the human needs in all rural, urban and industrial context, whereas the land use plan refers to a coherent set of decisions about the ways to achieve the desired use preferably on economic background. Thus, the land use planning is the systematic evaluation and assessment of a land and associated attributes for the purpose of identifying the best land use options beneficial to land owners or users without degrading the land resources or environment.

It includes not only the land owner or users, but also the policy or decision makers as well as economic experts for financial measures from planning stage or logistic planning to execution. However, the land use planning has been biased to its immediate relevance for its pursuits in education, though its relevance is more sensitizing in business management terms also. Let the concept of LUP be translated into land economics and subsequently into agri-business so that the essence of corporatization could be integrated with LUP. Economics works under two broad terms viz. demand and supply. Among many demand forces, population forces, income variation, technology application, market access and transportation facilities are vital for land economics. The accumulated impact of these forces promotes the demand for products or uses of a land. However, a land as being the productive factor does not need an increase in itself as it is fixed, but other productive factors like labour, capital and management are also combined with land and contribute significantly under a set of management. Of course, the area of a land is fixed, but the supply of products and land uses in a given land is variable.

\section{This is because}

I. The amount of labour, capital and management combines with land area may be changed to produce more outputs of produce or more products or land uses. 
II. If a new technology is introduced, it may change or upgrade the outputs in order to produce a larger amount of products from the fixed area of land.

III. Improved transportation may increase the supply and distribution of produce.

IV. Agri-business and entrepreneurship by facilitating a rural based supply chain for produces may sustain the land economics and insure poverty alleviation among the poor resource farmers.

V. Secured land ownership as in India is very positive for land economics, wherein framework for demand and supply for land use or products may be executed freely to achieve the mission.

Land is virtually a physical unit of the environment comprising basically of soil, climate, geology, hydrology, wherein soil as a physical factor of land is only manageable. This is because of which soil is frequently used as synonym to land for all practical purposes. Soil as a natural resource in the landscape is otherwise subject to respond to management in order to cause production to its suitable choice popularly known as land use like crops, vegetation, forest, plantation, pasture, forage, timber etc. Besides, soil cannot be comparable with animal or plant or rocks and minerals particularly for the purpose of any grouping due solely to complex type of its heterogeneity. In brief, soil as a natural resource is in continuum on the landscape, dynamically surrounded by climate, hydrology and soil site characteristics, wherein light radiation and sustainable management are two additional soil forming factors besides Dokucheaev-Jenny postulated known five factors [1].

Since soil is basically a resource intended for management by the farmers, who care for business, there is logistic to shift this business towards insured profitability, since more than 80 percent of Ethiopian population rests on this business. Thus, the importance of land economics is immense. Be sure that the key factor for success in this giant business lies on best agricultural practices in line with land use planning followed by the best business strategies. So, there must be a clear vision to empower the poor farmers with current reliable technological updating in order to compete with the emerging business environment and its processes, because the strength of any business depends on specific business process applied in line with excellence in production. Farmers are made aware to latest knowhow about business management process in order to enable them to adopt such process. In order to mobilize farmer's mindset to incline to business tips, the first and foremost option is to familiarize them with success stories of identical farmers in the adjoining farming areas simply to sensitize for being committed for farm business management.

Sushil Kumar, for example, in a village Tulsipur (Naugachia) of Bhagalpur district in Bihar (India) once brought some banana suckers and planted in his farm in the year 1971-72 with agronomic management inputs he learnt in Maharastra. The success story he planted was so reliably acceptable that other farmers not only in his village, but from adjoining villages started following this practice of banana cultivation. The adoption of banana cultivation was so revolutionary that within five years, entire Naugachia, Khagaria, Katihar and Purnea districts in India is known as "Kelanchal" i.e. Land of Banana. Importantly, the farmers never receive any encouragement in any way either through the state or central government, but the business zeal among the farming community of the zone left no stone untouched in order to make the profession profitable. Such examples, however, suffers from imbalanced business management process, though the outcome may be profitable, it cannot, however, be stable and sustainable. So, the farmers are made well trained with business process under farming system. In the modern scenario, the business process works in networking, wherein production at one end follows the product being supplied through a well defined supply chain covering the priority area of demand. Hence, the land economics has vast scope to address for soundness of a country. By and large, the concept of land economics lies on the practical framework of the land use planning, a tool based on land and soil evaluation.

The land use planning simply means for a systematic assessment of physical, social and economic factors in such a way so as to help the land users to select land-use options that may increase their productivity on sustainable basis. As we know, the land resources are limited and finite. It is projected that if the human population continues to increase at the present rate, there will be almost twice as many people on the globe in the next 50 years. So, the consequences are well understood for coming future, if not alert against ill-effects.

\section{A Case Study with Experience in India and Ethiopian Highlands}

The LUP is virtually an assessment for the purpose of identifying a specific land use option for the most remunerative return, but on sustainable basis. By this is meant that the LUP is intended for economic return with varying objectives within a common boundary of sustainability. A few years ago, a small farmer of Munger district of Bihar, India decided to use his small area of land (around $500 \mathrm{sq}$ metre) for growing some plants that can insure daily income of at least Indian Rs. 50 only in order to meet his minimum daily kitchen requirements. He started consulting experienced farmers and technical persons, but he was not satisfied. One day, he saw that some children forcibly plucking the flowers inside the residential premises of their neighbour. The said farmer witnessed this incidence and tried to inquire the background. He was well informed that on every day, huge quantity of flowers are used to worship in around 50 temples within 2-3 km radius. Since flowers were not abundantly available in the area, children in the morning did visit from door 
to door and pluck flowers for their parents to worship God (Ishwar) in temples.

The farmer immediately conceived a plan to grow and cultivate flowers in his small plot. However, flowers were seasonal or perennial and flowering differently in different months or seasons, though he was interested for getting flowers round the year. So, he started wandering from place to place in agricultural departments dealing with horticulture and floriculture with the same objective to find flower plants or seeds with different planting and sowing times to cover the whole year with flowers in his plot. Accordingly, he prepared a calendar of planting the flowers. His small plot was then laid out, but he left part of land for growing his cow.

The objective was economic based "To insure daily income to meet the family domestic requirement from his small piece of land" followed by a hypothesis "To find mixed type of flower plants in succession to cover a whole year in order to meet his expected demand". He tried exhaustibly to find a solution. It is of course a typical example how LUP can be translated on ground to a common man. Now, let us have some examples in Ethiopia. Ethiopia is crowned for Chats production particularly in the highlands, where soils are productive but with topographic limitations, where land use options are virtually unattended. Banana and sugarcane are also two important cash crops grown in Ethiopia, but suffer from proper land use options and are mostly grown in farmstead or kitchen garden. Similarly, there is need to introduce many fruit and vegetable crops in different parts of Ethiopia within the framework of LUP.

The wild varieties of a number of agricultural crops particularly spices (fenugreek), oilseeds (castor), vegetable (brinjal) in Ethiopia witness its golden past, but needs systematic documentation. However, soils of Ethiopia are uniquely interesting to support the values under LUP, though limitations based on landforms and topography are more highlighted at global platforms. There is thus need of economic priority to resource generation followed by LUP so that agricultural development in Ethiopian soils will come to its reality.

\section{Need for agri-business intervention with LUP}

If LUP-based agri-business system is operative, following issues could have been resolved:

i. The available business map/priorities of the area may indicate about degree of demand for land uses so that LUP team could recommend after due assessment.

ii. Professional business team normally looks for quick supply of the said demand from wherever the desired product is available for supply. Contrary to this, LUP- based agri-business team will explore the product or produce or land use only from the surrounding land based on evaluation.

iii. Agri-business intervention will facilitate the land owner to work with LUP team with a positive commitment in order to insure his professional benefits.

iv. Planning team as well as decision maker for LUP will support the project based on positive remarks of the business team.

v. With a successful land use plan, business team will be responsible to develop a supply chain system with the assured land use or produce from "farmer to warehouse to distributors to consumers".

vi. The LUP team will keep vigilance to the objective within the boundary of overall land and environmental sustainability.

\section{Quick Look To Agricultural Based Economy in India}

India has predominantly an agricultural based economy, wherein food production accounts for $26 \%$ of national GDP. Here, agriculture accounts for more than $60 \%$ of national employment. In a projected estimate, agriculture is growing only at $3.3 \%$ compared to industry that grows at the rate of $7.5 \%$ a year. There is tremendous scope in India to transform agriculture into corporate sector. Based on reports, India ranks first in the world (in 2012) in the production of bananas, mangoes, papayas, chickpea, ginger, okra, whole buffalo, goat milk and buffalo meat. India ranks second in the world in the production of sugarcane, rice, potatoes, wheat, garlic, groundnut (with shells), dry onion, green pea, pumpkin, gourds, cauliflower, tea, tomatoes, lentils, wheat and cow milk. Besides, the country's gross cropped area amounts to199 million hectares with a cropping intensity of $140 \%$. The net irrigated area is 89.9 million hectares with a total of 127 agro-climatic zones identified.

India's food processing sector ranks fifth in the world in exports, production and consumption. Major parts of the food processing sector are milled grain, sugar, edible oils, beverages and dairy products. It is further to note that India stands second in fruit production after Brazil and similarly second in vegetable production after China. In a general estimate, about 33 million tonnes of fruits and almost 70 million tonnes of vegetables are annually produced in India following a global market share of about $11 \%$ and $17.5 \%$, respectively. However, the fruits and vegetables are processed only to an extent hardly of 1 to $2 \%$ in India as compared to 70 to $80 \%$ in developed countries. Thus, there is a wide gap full of challenges that need opportunities to overcome in almost all sectors of Indian agriculture. The Government of India is, of course, offering incentives in agricultural fields, but there is need of transformation.

As a matter of fact, almost $80 \%$ of rural population contributes to the development of agriculture in different directions in India. However, the continued speedy process of urbanization in India has resulted in migration of rural people to the urban areas for non-farming business. Besides, the in-equilibrium between industrial and agricultural wage pattern and structure 
resulted into unrest and frustration which manifests in the form of violence and sufferings. The aim of this paper lies with the fact that traditional system in agriculture must get transformed for gross rural happiness in livelihood. This could be possible by generating system approach through land economics that works on demand and supply in the framework of land use planning followed by a well knitted supply chain process starting from farmers to consumers through distributors under the supervision of corporate sectors.

\section{Work Culture to Begin with Land Evaluation Under LUP}

Importantly, the soil is the soul or a building block of infinite lives, because it is foundation for survival and nourishment of such lives. The soil has its origin, its growth and its end. It is natural and takes several years to grow, develop, mature, reform and transform or even erode. Soil cannot be a waste unless it is washed out. It is not renewable and manufactured. As it is a resource, it is subject to production that necessitates site-specific management inputs. It works in critical zone concept (surface-rhizosphere-underground) and influences three basic needs of life viz. ecosystem, food and water besides influencing the climate, biodiversity, energy and livelihood. As a soil system in agriculture, it needs an integrated management skill, but often lacks an acceptable "work culture" within the framework of soil science; for which a global mandate needs to be develop, accepted and practiced in order to attain a balanced soil sustainability, which may be a part of governance in land economics. Soil belongs to an open system in its environment that may be both natural and synthetic or even artificial. So, for any exercise to monitor the soil health and fertility status as often we follow the soil testing of the top soil $(0-20 \mathrm{~cm})$, one has to move, prior to this, for a systematic examination of whole soil (pedon) as outlined below.

a. Evaluate the soil (pedon) for deciding its actual and potential productivity/capability.

b. Identify the associated limitations (correctable/ non-correctable) following the subsequent amelioration, reclamation, mitigation and overall improvement through locally available management and/or technical inputs.

c. Fix suitability of land use choice in a specific set (crop rotation in case of agronomic crops) for the most remunerative return..

d. Decide the fertility level of soil and recommend how much a particular nutrient is applied in the most preferred way i.e. balanced form to enhance the nutrient use efficiencies and so.

This should be made bare mandatory prior to start with crop cultivation or similar land uses. By furnishing above exercise, soil related prescriptions are made available in the form of a written document covering all pedogenic, physical, chemical, microbiological, biochemical, nutritional, pathologic, heavy metal, arsenic and biodiversity issues. Such system approach can safely predict the soil health management of a soil for restoration of total soil health. Soil or even land may be natural, but its management is almost man-made particularly for the purpose of agriculture, wherein the land economics is overall indicator, if approaches are reliably tenable.

A soil with full prescriptions being provided within the above work culture by concerned professionals may then be transferred to Agronomist, Horticulturalist or Farm Manager or farmers, who could simply follow the said prescriptions and management options within the recommended package of practices for given crops or plantation or land use. In fact, the manager on land/ soil management takes decision based on some principles and sets certain specifications for choice he can meet. If the manager is novice or irresponsible, he can hardly meet the goal and his business ultimately fails. So, the land economics may be a source of auditing for one's professional endeavour in totality.

Research is merely a means or process of relating a theory to facts or factual relationships. The function of science is to identify and solve the problems. In fact, the essence of science is to test the hypothesis, a process of going from fact to theory. Hypothesis is to predict the facts through verification and so it is a tentative answer or solution. Land research is closely tied with governance, policies and executive decision.

\section{Supply Chain of Land Uses or Produces}

Virtually, the concept of supply chain of land uses or produces is neither fully understood among rural farmers nor accepted, though Food Industries are running around urban areas in different cities. The existing drawbacks need to be addressed on priority basis to flourish corporatization with land uses. Farmers in general are not aware of the merit of supply chain for their produces. So, there is need for visualization of this system among the rural communities through training, demonstration and documentary films. There is need to centralize the planning in supply chain of land uses or produces through distribution into a single management system using IT tools as prevalent in reputed industry. The corporate sectors may also take a lead to implement a planning system to judge the existing land use scenario and make management decisions based upon various situations including storage of raw materials (land uses), processing and finished goods from point-of-origin (farmers) to point-of-consumption (markets) in order to insure the best competitive price to the farmers. Once the farmers get satisfied with economic outcome, they themselves feel eager to stimulate such wonderful approach under land economics for their overall economic promotion. But, further refinement is mandatory by experts in classical economics from across the globe.

\section{Poverty alleviation: a key issue}

As opined earlier, only two major successions could be broadly recognized viz. (i) Agriculture through hunting and (ii) Agriculture through ploughing, sowing or planting and harvesting 
[2]. In the second succession, there have been numerous reforms including reforms during green revolution, mostly technological reforms. Such reforms have definitely solved the food security issues in a big way. But, farmers are by and large poor in terms of livelihood and economic growth. This is of global concern even. However, it is of strong logical understanding to expand the long existing second agricultural succession to its third counterpart (succession), wherein farming (ploughing and harvesting) is made closely tagged with "processing, value addition and marketing at the farmer's door" itself without allowing any role of a middleman. If we accomplish the attainment of the emerging agricultural succession in reality, it will be proved a breakthrough towards alleviation of poverty among farming communities. However, the strategic planning may be developed as below:

a. To enrich the infra-structures as the assumptions for the success towards adoption of the respective management as well as technical training at farmer's doors viz. Secured land ownership, road, water, electricity, banks, self-help groups, internet access/training, transport and market access including location specific processing and other post harvest and value addition plants to be installed.

b. To appreciate some nucleus villages (based on approved standard) for adoption of reliable and proven technologies being approved with assured outcome (produce).

c. To organize frequent trainings on setting-up of agribased industries as well as food processing and value addition plants for site-specific agri-based products.

d. To set up a market complex for assuring the normal sale procedure for different agricultural products in a way to fetch high price to the farmer without involvement of middlemen.

e. To involve corporate sectors in rural area and get the farmers tagged to begin with new succession of sustainable agricultural production to sustain livelihood and economic growth.

The proposed set rules as qualitatively outlined above may help to develop a framework of agri-business management in a way to assure farmers with maximum profit. Specialized people may sit together to formulate a strategic plan to shift whole traditional farming system into corporate sector within the framework of land use planning (LUP), wherein farmers will be the main actors. That will be the true outcome of the third agricultural succession. As a consequence, farmers will no more remain then poor, if global food security campaign is designed and approved in line with above basic set rules. Accordingly, the farmers will keep adhered to the following responsibilities:

A. Let a farmer sow or plant the seed or seedling following the recommended technology and available inputs (preferably locally) strictly on LUP model.

B. Let him harvest the product under his own control following the improved technology (already existing in most parts).

C. Farmer must have liberty to store his produce or go for post harvest technology/processing or even value addition to fetch a good price. Let farmers be sole responsible in planning and decision process of marketabe produce through some suitable supply chain process offered by corporate sectors.

D. Farmers must be exposed for opportunities in marketing (import/export) and that too under their direct control to fetch the profits with corporate sectors involved.

The above four point programme at farmer's door (direct control) virtually needs encouragement/ approval by the policy makers (Government), agricultural universities, cooperative bodies and extension workers. Every farmer with landed property is legalised to furnish all four steps at his door. Other professions like dairy, goatry, mushroom production, apiary etc are additional to boost up the economics. Once the programme is legalised just by adopting a village as the Nucleus Village, the farmers will get excited towards its adoption and this will be a true success story towards poverty alleviation in India. Obviously, the entire framework lies on how best we manage the land for quality produce following the pillars viz. productivity, safety, profitability and sustainability of land resource and so the land economics, which will shape the real economic picture of a nation.

\section{Conservation Agriculture}

The bare truth of conservation agriculture (CA) is to minimize the challenges imposed by climate change through $\mathrm{C}$-sequestration by keeping the land covered with vegetation and/or crop residues round the year with no-till or zero tillage. The CA follows the principles of restoring the biodiversity and pedo-ecosystem. The selection of site-specific crop rotation based on parametric land evaluation followed by land use suitability identification may be the prerequisite for a given field plot. In this particular agriculture, one suitable cover crop is identified between two main crops based on nature and height of main crops already identified and such exercise needs exhaustive experience with indigenous knowledge and this may enable a soil scientist to work together with farmers in an interactive environment. Then, fix the balanced nutrition to the crops in rotation (including cover crops) based on soil fertility evaluation.

Soil covered with vegetation round the year may buffer the diurnal temperature change and minimize the organic matter decay considerably, thus, creating a congenial environment for C-sequestration. As farmers seek to change from chemicalbased conventional farming systems to more sustainable kinds of agriculture i.e. organic farming, which may be adopted in conservation agriculture (CA) successfully, wherein one has to be sincere to use accessible organic sources like 
a. Crop residues comprising of both shoot and root residues

b. Plant debris in suitable sizes $(<2 \mathrm{~mm}$ but larger than $0.053 \mathrm{~mm}$ )

c. Humus (decomposed materials less than $0.053 \mathrm{~mm}$ that are dominated by molecules stuck to soil minerals).

d. Compost, FYM, vermicompost and others, which are prepared locally [3]. In CA, farmers should essentially learn, ahead of managing the organic resources, how to sustain soil moisture by managing organic source itself.

The amount of plant available water can be determined by two parameters:

I. The lower limit i.e. the amount of water in the soil that plants cannot extract or utilize.

II. The upper drained limit i.e. the amount of water that can be held against drainage. The difference between the upper and lower limit does define the potential available water holding capacity (PAWC) of a given soil. If this value can be increased even marginally through CA, it will help to sustain or simply maintain or optimize the potential productivity by allowing the soil to retain more water each time that rains. For any given clay content, as organic carbon increases the upper limit, the PAWC of the soil increases further [3]. The amount of carbon in a soil results from the balance between inputs (plant residues or other sources) and losses (microbial decomposition and associated mineralization). Obviously, land economics will cover all these production processes through land use planning leading to adoption of conservation agriculture followed by a smart supply chain within the direct control of farmers.

\section{Conclusion}

Land economics is a powerful tool to control the process of land use planning through land and soil evaluation following the emerging need for adoption of conservation agriculture and subsequent application of a suitable supply chain system for the land uses or produces at the door of farmers. A success story of this programme will insure a long pending demand of poverty alleviation, climate change mitigation and adaptation and quality food production organically even. However, it requires governance and thus a strong government support across the globe. The FAO must work exhaustively on this line to approve the criteria of how best land economics would be the driving force to streamline the approaches under LUP leading to poverty alleviation, continued carbon sequestration, organic farming and quality food production by restoring the overall soil health. The author has recently developed the Indian system of Soil Classification based on land use options as the ultimate objective $[1,4]$ and needs to be linked directly with land economics. However, there is need to develop a common working principle with classical framework of business management over land economics.

\section{References}

1. Mishra BB (2015) Soil Classification: Issues and Opportunities for Indian System, the 26th Dr. SP Raychaudhuri Memorial Lecture, 19th October, 2015, NBSS \& LUP, Nagpur, Journal of the Indian Society of Soil Science 63 (Supple): S41-S52.

2. Mishra BB (2014) Promoting productivity through R \& D vs Poverty Alleviation. Business of Agriculture pp. 31-35.

3. Bowden Bill (2009) Agribusiness Crop Updates. Department of Agriculture and Food, Western Australia.

4. Mishra BB (2016) Indian System of Soil Classification: A way Forward. Agri Res \& Tech: Open Access J 3(2): 555606.

\begin{tabular}{l} 
Your next submission with Juniper Publishers \\
will reach you the below assets \\
- Quality Editorial service \\
- Swift Peer Review \\
- Reprints availability \\
- E-prints Service \\
- Manuscript Podcast for convenient understanding \\
- Global attainment for your research \\
- Manuscript accessibility in different formats \\
( Pdf, E-pub, Full Text, Audio) \\
- Unceasing customer service \\
Track the below URL for one-step submission \\
https://juniperpublishers.com/online-submission.php \\
\hline
\end{tabular}

